\title{
MENINGKATKAN PRESTASI BELAJAR MAHASISWA MENGGUNAKAN MODEL PEMBELAJARAN KOLABORATIF DENGAN PENDEKATAN BLENDED LEARNING
}

\author{
Santhy Givend Pandie ${ }^{1}$, Imanuel Yosafat Hadi Manapa ${ }^{2}$ \\ Pendidikan Bahasa Inggris, Universitas Tribuana Kalabahi ${ }^{1}$ \\ Matematika, Universitas Tribuana Kalabahi ${ }^{2}$ \\ Email: santhypandie21@gmail.com ${ }^{1}$
}

\begin{abstract}
Abstrak
Aktivitas pembelajaran matakuliah teaching-learning strategy (TLS) dilakukan secara shifting sebagai akibat dari Pandemi Covid-19. Aktivitas pembelajaran secara shifting mengakibatkan adanya pengurangan durasi tatap muka, sehingga kebutuhan mahasiswa untuk mempelajari teori dan melaksanakan praktik tidak terakomodasi secara baik. Hal ini berdampak langsung pada menurunnya prestasi belajar mahasiswa. Tujuan dari penelitian ini adalah untuk meningkatkan prestasi belajar mahasiswa dan mengakomodasi kebutuhan mahasiswa menggunakan model pembelajaran kolaboratif dengan pendekatan blended learning. Model pembelajaran kolaboratif diimplementasikan pada setiap aktivitas belajar baik secara tatap muka maupun daring. Pendekatan blended learning dimunculkan pada aktivitas pembelajaran yakni mempelajari teori dilakukan secara tatap muka sedangkan praktiknya dilakukan secara daring. Penelitian ini merupakan penelitian tindakan kelas dan dilakukan sebanyak tiga siklus. Hasil penelitian menunjukan bahwa terdapat peningkatan prestasi belajar mahasiswa untuk setiap siklus. Penerapan model pembelajaran dengan pendekatan ini dapat mengakomodasi kebutuhan mahasiswa untuk mempelajari teori dan praktiknya. Hal ini dapat digunakan sebagai alternatif solusi selama era pandemi dengan aktivitas pembelajaran secara shifting.

Kata Kunci : model pembelajaran kolaboratif, pendekatan blended learning, prestasi belajar mahasiswa
\end{abstract}

\begin{abstract}
Teaching-learning strategy (TLS) course learning activities are carried out in shifting as a result of the Covid-19 Pandemic. Shifting learning activities result in a reduction of the duration of face-to-face so that the need for students to study theory and carry out practices is not well accommodated. This has a direct impact on the decrease in student learning achievement. The purpose of this research is to improve student learning achievement and accommodate student needs using a collaborative learning model with a blended learning approach. Collaborative learning models are implemented in every learning activity both face-to-face and online. The blended learning approach is presented in learning activities that are learning theory done face-to-face while the practice is done online. This research was a class action study and conducted in three cycles. The results showed that there was an improvement in student learning achievement for each cycle. The application of learning models with this approach can accommodate the needs of students to learn theory and practice. It can be used as an alternative solution during the pandemic era with shifting learning activities.
\end{abstract}

Key Words : collaborative learning model, blended learning approach, student learning achievement

\section{PENDAHULUAN}

Pendidikan merupakan salah satu kebutuhan utama bagi setiap individu. Pendidikan menpengaruhi kualitas sumber daya manusia (SDM) dan berperan penting guna menghadapi perkembangan serta tantangan zaman. Memaknai pentingnya peranan pendidikan bagi kehidupan manusia, maka Universitas Tribuana
Kalabahi mempunyai visi dan misi untuk menghasilkan lulusan yang unggul serta kompetitif dibidangnya. Khususnya pada program studi pendidikan bahasa inggris, menghasilkan calon pendidik yang inovatif dan profesional pada bidangnya adalah hal yang yang mutlak. Lulusan dari program studi bahasa inggris diharapkan mempunyai kompetensi dalam hal strategi 
belajar mengajar. Dengan demikian matakuliah Teaching Learning Strategi $(T L S)$ atau strategi belajar mengajar menjadi matakuliah wajib program studi. Matakuliah TLS bertujuan agar mahasiswa dapat mengenal teori dan aplikasi terkait model, pendekatan, strategi, metode dan teknik pembelajaran. Selain itu, TLS merupakan matakuliah prasyarat untuk matakuliah microteaching dan Program Pengenalan Lapangan (PPL).

Proses perkuliahan sebaiknya mengutamakan proses interaksi dua arah yaitu interaksi mahasiswa ke dosen maupun sebaliknya serta interaksi antar mahasiswa. Selain itu, belajar membutuhkan pengalaman belajar yang bermakna. Kegiatan belajar secara spesifik didefinisikan sebagai refleksi dalam melakukan sesuatu [1]. Mengaktifkan interaksi antar mahasiswa sangat diperlukan. Pengetahuan tidak dapat diserap secara pasif dari lingkungan melainkan disusun oleh seseorang sebagai rangkaian interaksi mereka [2]. Interaksi dapat dimaknai sebagai kolaborasi antar mahasiswa. Interaksi yang kolaboratif merupakan salah satu bentuk konstruktivisme sosial yang dapat membentuk proses kognitif individu [3].

Pembelajaran yang mengutamakan interaksi dan berdasarkan aliran kontruktivisme sosial adalah pembelajaran kolaboratif [4]. Pembelajaran kolaboratif adalah metode pembelajaran yang banyak digunakan, tetapi potensi pembelajaran metode pembelajaran ini sering kurang dioptimalkan saat penerapannya [5]. Hal yang tidak disadari adalah pembelajaran kolaboratif cenderung lebih sesuai pada pendidikan tinggi [6].

Pada penerapannya, pembelajaran kolaboratif berarti mahasiswa bekerja secara berpasangan atau dalam kelompok kecil untuk mencapai tujuan bersama [7].
Pada pembelajaran kolaboratif peran dosen hanya sebagai observer dan tidak melakukan intervensi secara mendalam. Pembelajaran kolaboratif memiliki tiga aspek penting. Pertama, desain pembelajaran dirancang untuk mahasiswa sehingga peran dosen hanya sebagai observer. Kedua, adanya kerjasama kelompok secara aktif untuk mencapai tujuan yang diinginkan. Ketiga, terjadinya proses pembelajaran yang penuh makna.

Referensi [8] mengemukakan sintaks pembelajaran kolaboratif adalah sebagai berikut.

1. Para mahasiswa dalam kelompok menetapkan tujuan belajar dan membagi tugas sendiri-sendiri dalam kelompok.

2. Kelompok kolaboratif bekerja secara bersinergi mengidentifikasi, mendemontrasikan, meneliti, menganalisis, dan memformulasikan jawaban-jawaban tugas atau masalah yang ditemukan sendiri.

3. Setelah kelompok kolaboratif menyepakati hasil pemecahan masalah, masing-masing mahasiswa menulis laporan sendiri-sendiri secara lengkap.

4. Dosen meminta salah satu kelompok secara acak ntuk melakukan presentasi hasil diskusi kelompok kolaboratifnya di depan kelas, mahasiswa pada kelompok lain mengamati, mencermati, dan membandingkan hasil presentasi.

5. Masing-masing mahasiswa dalam kelompok kolaboratif melakukan elaborasi, inferensi, dan revisi terhadap laporan yang dikumpukan.

6. Laporan masing-masing mahasiswa terhadap tugas-tugas yang telah dikumpulkan, disusun perkelompok kolaboratif.

7. Laporan mahasiswa dikoreksi, dikomentari, dinilai, dikembalikan pada pertemuan berikutnya, dan didiskusikan

Teknologi pembelajaran sebagai sarana untuk mempercepat proses inovasi dunia 
pendidikan untuk mampu menghasilkan ide, proses, prosedur, dan hasil yang berhubungan secara langsung maupun tidak langsung dengan berbagai sumber dan cara belajar [9]. Seiring dengan perkembangan ilmu pengetahuan dan teknologi, pembelajaran yang biasanya dilakukan secara tatap muka kini dapat diganti dengan pembelajaran secara daring. Penggunaan teknologi pembelajaran daring terbukti efektif meningkatkan prestasi belajar mahasiswa dan kualitas pembelajaran di pendidikan tinggi [10]. Bagi mahasiswa pembelajaran menggunakan media online memberikan kepuasan akan interaksi mereka dengan sumber belajar dan interaksi antara mahasiswa [11].

Sebuah pemikiran lain muncul yaitu teknologi pembelajaran daring yang digunakan pada pembelajaran daring adalah sebagai komplemen pembelajaran yang dilakukan secara tatap muka. Pembelajaran ini kemudian disebut sebagai blended learning. Pembelajaran ini mengkombinasikan dua bidang perhatian yakni pendidikan dan teknologi pendidikan [12]. Blended learning terbagi menjadi dua model yakni program flow model dan core and spoke. Model pertama mengintegrasikan penggunaan media kedalam kurikulum dan silabus sebagai unsur pembelajaran. Lebih lanjut, model yang kedua merancang proses pembelajaran secara tatap muka atau berbasis daring menggunakan media online. Pada kenyataannya pembelajaran dengan blended learning merupakan kombinasi dari keduanya [13]. Pengertian yang sesuai untuk blended learning adalah pembelajaran yang menyatukan pembelajaran secara tatap muka dan pembelajaran secara daring [14]. Tujuan dari blended learning agar dapat melengkapi kekurangan yang ada pada pembelajaran dengan tatap muka [15].
Pada tahun 2020 pelaksanaan perkuliahan di Universitas Tribuana Kalabahi serba darurat dan sangat fleksibel mengikuti aturan penyelenggaraan pembelajaran di masa pandemi Covid-19. Pada bulan Desember 2020 di Kabupaten Alor letak universitas ini, beralih dari zona kuning ke zona hijau berdasarkan tingkat penyebaran virus covid-19. Menurut panduan penyelenggaraan pembelajaran oleh kementrian pendidikan dan kebudayaan, pembelajaran secara tatap muka diperkenankan di zona hijau [16]. Walaupun demikian, mencermati dampak dari penyebaran virus ini maka universitas mengambil kebijakan situasional terkait pelaksanaan pembelajaran selama era pandemi.

Kebijakan pelaksanaan pembelajaran yang diterapkan pada bulan tersebut dibedakan menjadi kelas dengan rombongan belajar (rombel) besar dan kecil. Untuk kelas dengan rombel besar dilakukan secara daring sedangkan pada rombel kecil dilakukan secara shifting (bergantian). Selain itu, diterapkan juga pembatasan jam kerja bagi setiap dosen selama era pandemi Covid-19. Kendala yang ditemui saat pembelajaran secara shifting adalah masalah durasi pertemuan secara tatap muka. Matakuliah TLS memiliki bobot 3 SKS dan hanya dilakukan 75 menit untuk setiap shift. Hal ini dirasa merugikan mahasiswa terkait dengan kualitas pembelajaran. Proses pembelajaran menjadi tidak luwes, terkesan terburuburu, dan prestasi belajar mahasiswa menurun drastis akibat dari pandemi dan kebijakan yang diambil oleh pihak universitas.

Normalnya, kegiatan pembelajaran pada matakuliah TLS diawali dengan mempelajari teori terkait suatu model pembelajaran, merancang rencana pelaksanaan pembelajaran, dan diakhiri dengan simulasi penerapan model 
pembelajaran yang dipelajari serta evaluasi. Fakta yang terjadi adalah tahapan pembelajaran sering tidak mencapai tahapan simulasi dan evaluasi karena adanya pengurangan durasi.

Walaupun dalam kondisi pandemi, ketercapaian tujuan dan ketuntasan belajar adalah hal yang sangat penting untuk dipertimbangkan. Oleh karena itu, peneliti berupaya untuk mengatasi hal tersebut dengan memadukan model pembelajaran kolaboratif dengan pendekatan blended learning. Pendekatan blended learning sebagai wadah pemanfaatan teknologi yang menjadi salah satu solusi selama era pandemi Covid-19 [17]. Pada penelitian ini, prosedur implementasi model pembelajaran kolaboratif dengan pendekatan blended learning dengan mengadopsi dan memodifikasi sintaksnya. Tahapan pembelajaran dengan pendekatan blended learning yaitu orientasi, kegiatan inti, serta pelaporan dan umpan balik [18]. Modifikasi penerapan model pembelajaran kolaboratif dengan pendekatan blended learning pada penelitian ini terletak pada jenis aktivitas pembelajarannya. Apabila pelaksanaan pembelajaran secara tatap muka belum tuntas maka dilanjutkan dengan pembelajaran secara daring dengan waktu yang disepakati bersama mahasiswa. Adapun media yang digunakan selama pembelajaran secara daring adalah zoom, google meet, live streaming facebook, dan youtube.

Memadukan pembelajaran tatap muka dan daring dapat meningkatkan kepuasan dosen dan mahasiswa dengan adanya ketuntasan dan ketercapaian tujuan pembelajaran. Dengan adanya kondisi pandemi seperti ini diharapkan implementasi model pembelajaran kolaboratif yang dimodifikasi dengan pendekatan blended learning dapat meningkatkan kualitas pembelajaran dan meningkatkan prestasi belajar mahasiswa.
Lebih lanjut, dengan model pembelajaran dan pendekatan ini diharapkan dapat mengatasi masalah ketercapaian dan ketuntasan belajar mahasiswa yang terkendala akibat aktivitas pembelajaran yang dilakukan secara shifting selama era pandemi.

\section{METODE}

Metode penelitian yang digunakan pada penelitian ini adalah penelitian tindakan kelas. Tujuan penelitian tindakan kelas adalah untuk meningkatkan kualitas pembelajaran dan prestasi hasil belajar. Terdapat empat tahap pada penelitian tindakan kelas yakni perencanaan, tindakan, observasi, dan refleksi [19]. Rangkaian tahapan pada penelitian tindakan kelas saat pandemi Covid-19 tidak seperti pada umumnya namun menemukan solusi terbaik menjadi fokus utama penelitian ini [17]. Penelitian ini merupakan serangkaian tindakan kelas yang dilakukan sebanyak tiga siklus. Tujuan utama dari penelitian tindakan kelas ini adalah untuk meningkatkan prestasi mahasiswa pada matakuliah TLS.

Sumber data penelitian ini berasal dari 17 mahasiswa program studi pendidikan bahasa inggris semester $\mathrm{V}$ tahun ajaran 2019/2020. Penelitian dilakukan pada bulan Desember 2020. Data dikumpulkan menggunakan metode tes prestasi belajar dan lembar observasi. Metode tes digunakan untuk mengevaluasi pemahaman mahasiswa terkait materi $T L S$, kemampuan mahasiswa untuk merancang RPP sesuai dengan model pembelajaran yang telah dipelajari, kesesuaian media pembelajaran yang digunakan mahasiswa dengan materi ajar, kemampuan mahasiswa untuk mensimulasikan kegiatan pembelajaran yang telah dirancang pada RPP. Adapun KKM yang ditentukan oleh program studi bahasa inggris 75 . Indikator keberhasilan siklus berdasarkan jumlah mahasiswa yang mencapai KKM dari 
jumlah total keseluruhan mahasiswa serta adanya peningkatan nilai rata-rata mahasiswa untuk setiap siklus. Analisis data menggunakan metode statistik deskriptif yakni ukuran tendensi dan dispersi data untuk mendapatkan karakteristik data untuk setiap siklus.

\section{HASIL DAN PEMBAHASAN}

Berikut adalah penyajian data mentah prestasi belajar siswa matakuliah $T L S$ untuk setiap Siklus.

\section{Tabel 1. Data Prestasi Belajar} Mahasiswa Tiap Siklus

\begin{tabular}{ccccccc}
\hline \multirow{2}{*}{ Kode } & \multicolumn{5}{c}{ Skor Hasil Belajar } \\
\cline { 2 - 7 } Mahasiswa & \multicolumn{2}{c}{ Siklus I } & \multicolumn{2}{c}{ Siklus II } & Siklus III \\
\cline { 2 - 6 } & Nilai & Ket & Nilai & Ket & Nilai & Ket \\
\hline M-1 & 68 & TL & 80 & L & 90 & L \\
M-2 & 66 & TL & 70 & L & 80 & L \\
M-3 & 70 & L & 80 & L & 90 & L \\
M-4 & 68 & TL & 74 & L & 80 & L \\
M-5 & 76 & L & 76 & L & 76 & L \\
M-6 & 70 & L & 76 & L & 84 & L \\
M-7 & 76 & L & 78 & L & 80 & L \\
M-8 & 76 & L & 78 & L & 80 & L \\
M-9 & 70 & L & 80 & L & 80 & L \\
M-10 & 58 & TL & 66 & TL & 72 & L \\
M-11 & 60 & TL & 70 & L & 76 & L \\
M-12 & 62 & TL & 66 & TL & 76 & L \\
M-13 & 70 & L & 76 & L & 80 & L \\
M-14 & 62 & TL & 66 & TL & 66 & TL \\
M-15 & 70 & L & 80 & L & 80 & L \\
M-16 & 66 & TL & 76 & L & 80 & L \\
M-17 & 70 & L & 70 & L & 76 & L \\
\hline
\end{tabular}

Data pada Tabel 1 adalah data prestasi belajar siswa yang diperoleh berdasarkan hasil evaluasi pada setiap tiap siklus. Data yang diperoleh pada tiap siklus menjadi acuan perbaikan siklus -siklus selanjutnya. Acuan perbaikan menitik beratkan pada mahasiswa yang tidak mencapai Kriteria Ketuntasan Minimal (KKM). Mahasiswa yang mencapai KKM diberikan keterangan lulus (L) sedangkan untuk mahasiswa yang tidak mencapai KKM diberikan keterangan tidak lulus (TL). Bagi mahasiswa yang mencapai kriteria TL selanjutnya dilakukan analisis kebutuhan dan kesulitan berajar kemudian diberikan penguatan atau reinforcement. Hasil pengolahan data menggunakan statistik deskriptif disajikan pada Tabel II kemudian dilakukan interpretasi keberhasilan tiap-tiap siklus.

\section{Tabel 2. Hasil Pengolahan Data Statistik} Deskriptif Tiap Siklus

\begin{tabular}{lrrr}
\hline \multirow{2}{*}{$\begin{array}{c}\text { Hasil Analisis Statistik } \\
\text { Dekriptif }\end{array}$} & \multicolumn{3}{c}{ Siklus } \\
\cline { 2 - 4 } & \multicolumn{1}{c}{ I } & \multicolumn{1}{c}{ II } & \multicolumn{1}{c}{ II } \\
\hline Mencapai KKM & 9 & 14 & 16 \\
Tidak Mencapai KKM & 8 & 3 & 1 \\
Persentase Mencapai KKM & $52 \%$ & $73 \%$ & $94 \%$ \\
Persentase Tidak Mencapai & $48 \%$ & $37 \%$ & $6 \%$ \\
KKM & & & \\
Nilai Rata - rata & 68 & 74 & 79 \\
Nilai Tertinggi & 76 & 80 & 90 \\
Nilai Terendah & 58 & 66 & 66 \\
Standar Deviasi & 5.42 & 5.19 & 5.74 \\
\hline
\end{tabular}

\section{Siklus I}

Berdasarkan data pada Tabel 1 pada siklus pertama terdapat 8 mahasiswa yang tidak mencapai KKM yaitu mahasiswa dengan kode M-10, M-11, M-12, M-14, dan M-16. Berdasarkan Tabel 2, persentase mahasiswa yang mencapai KKM dalam satu kelas sebesar $52 \%$, dengan nilai rata rata 68 , nilai tertinggi 76 , nilai terendah 58 , dan standar deviasi 5,42. Jika dilihat dari nilai rata-rata untuk skala kelas, kebanyakan mahasiswa yang tidak mencapai KKM. Selanjutnya nilai standar deviasi menunjukkan bahwa rata-rata penyebaran data prestasi belajar mahasiswa dari reratanya. Standar deviasi pada siklus I sebesar 5,42 dengan nilai reratanya 68 , karena nilai rerata kelas tidak mencapai KKM maka dapat diartikan bahwa rerata penyebaran nilai mahasiswa sejauh 5,42 dengan kecenderungan jarak setiap datanya berada di bawah KKM.

Berdasarkan hasil analisis tersebut kemudian dilanjutkan dengan identifikasi permasalahan berdasarkan hasil yang diperoleh pada siklus I melalui observasi di kelas dan wawancara kepada mahasiswa. Hasil tersebut disebabkan oleh mahasiswa yang belum terbiasa bekerja dalam 
kelompok yang kolaboratif. Pada siklus I materi yang dipelajari adalah model pembelajaran kooperatif. Mahasiswa ditugaskan untuk mencari tentang teori pembelajaran kooperatif, jenis-jenis pembelajaran kooperatif, mendesain RPP sesuai dengan metode pembelajaran, pendekatan, teknik, dan strategi yang ada pada pembelajaran kooperatif hingga mendemonstrasikannya. Pendekatan blended learning digunakan untuk menemonstrasikan pembelajaran kooperatif dilakukan secara daring dengan waktu yang ditentukan oleh guru. Akibat dari mahasiswa yang tidak bisa bekerja secara kolaboratif nampak pada pemahaman tentang materi model pembelajaran kooperatif dan penyusunan RPP yang tidak mencerminkan prinsip prinsip pembelajaran kooperatif. Hasil evaluasi dan observasi ini kemudian digunakan sebagai acuan pada siklus berikutnya.

\section{Siklus II}

Berdasarkan data pada Tabel 1 pada siklus kedua terdapat 3 mahasiswa yang tidak mencapai KKM yaitu mahasiswa dengan kode M-10, M-12, dan M-14. Hal tersebut memberikan arti bahwa terdapat peningkatan jumlah mahasiswa yang mencapai KKM. Berdasarkan Tabel 2, persentase mahasiswa yang mencapai KKM dalam satu kelas sebesar $73 \%$, dengan nilai rata rata 74 , nilai tertinggi 80 , nilai terendah 66, dan standar deviasi 5,19. Jika dilihat dari nilai rata-rata untuk skala kelas, kebanyakan mahasiswa yang telah mencapai KKM pada siklus kedua. Selanjutnya nilai standar deviasi menunjukan bahwa rata-rata penyebaran data prestasi belajar mahasiswa dari reratanya. Standar deviasi pada siklus II sebesar 5,19 dengan nilai reratanya 74, karena nilai rerata kelas telah mencapai KKM maka dapat diartikan bahwa rerata penyebaran nilai kelas sejauh 5,19 dengan kecenderungan jarak setiap datanya berada diatas KKM.

Berdasarkan hasil analisis tersebut kemudian diidentifikasi permasalahan yang diperoleh pada siklus II melalui observasi dikelas dan wawancara kepada mahasiswa. Pada siklus kedua mahasiswa mulai terbiasa bekerja secara kolaboratif. Dosen memberikan perhatian khusus bagi mahasiswa yang belum mencapai KKM pada siklus I sehingga beberapa mahasiswa dapat mencapai KKM yang ditetapkan. Materi ajar pada siklus II adalah discovery learning. Pada siklus ini, pemahaman mahasiswa terkait model pembelajaran discovery learning cukup baik. Desain RPP yang dibuat oleh mahasiswa sesuai dengan prinsip pembelajaran discovery learning. Selanjutnya, simulasi pembelajaran yang dilakukan secara daring telah menunjukan perubahan yang lebih baik daripada siklus sebelumnya.

\section{Siklus III}

Berdasarkan data pada Tabel 1 pada siklus ini hanya terdapat satu orang mahasiswa yang tidak mencapai KKM yaitu mahasiswa dengan kode M-14. Hal tersebut memberikan arti bahwa terdapat peningkatan yang signifikan jumlah mahasiswa yang mencapai KKM. Berdasarkan Tabel 2, persentase mahasiswa yang mencapai KKM dalam satu kelas sebesar 94\%, dengan nilai rata rata 79 , nilai tertinggi 90 , nilai terendah 66 , dan standar deviasi 5,74. Jika dilihat dari nilai rata-rata untuk skala kelas, hampir seluruh mahasiswa yang telah mencapai KKM pada siklus ini. Selanjutnya nilai standar deviasi pada siklus III sebesar 5,74 dengan nilai reratanya 79 , karena nilai rerata kelas telah mencapai KKM maka dapat diartikan bahwa rerata penyebaran nilai kelas sejauh 5,74 dengan kecenderungan jarak setiap datanya berada diatas KKM. Materi yang dipelajari pada siklus ini adalah model pembelajaran 
inquiry. Pada siklus ini, terdapat peningkatan yang signifikan dari segi pemahaman, perancangan desain pembelajaran, dan simulasi model pembelajaran oleh mahasiswa dengan pencapaian yang lebih baik daripada dua siklus sebelumnya.

Akibat adanya pandemi Covid-19 proses pembelajaran menjadi tidak optimal dan prestasi belajar mahasiswa menjadi menurun. Pembelajaran dengan menggunakan pendekatan blended learning pada implementasinya bukanlah sebagai pembelajaran secara tatap muka dan daring yang dipadukan serta dilakukan secara bersamaan dengan memanfaatkan teknologi pembelajaran. Blended learning juga dapat diimplementasikan pada waktu yang berbeda antara aktivitas pembelajaran secara tatap muka dan daring.

Masalah utama yang melandasi dilakukannya penelitian ini adalah mahasiswa harus mempelajari teori dan melaksanakan praktek dalam waktu yang bersamaan namun terkendala karena pembatasan waktu belajar. Hal tersebut dapat diminalisir dampaknya dengan menggunakan model pembelajaran kolaboratif dengan pendekatan blended learning yang dimodifikasi. Implementasi dari hal tersebut dapat dikatakan berhasil dengan adanya peningkatan prestasi belajar mahasiswa pada setiap siklus. Dampak positifnya adalah kebutuhan mahasiswa untuk mempelajari teori dan praktek dapat terakomodasi dengan baik. Selain itu, untuk demonstrasi yang dilakukan secara daring mahasiswa diuntungkan dengan tidak perlu mengkondisikan ruangan dan mahasiswa lain yang berperan sebagai siswa untuk belajar, sehingga dapat menghemat waktu.

\section{SIMPULAN}

Berdasarkan hasil analisis setiap siklus diperoleh simpulan bahwa implementasi model pembelajaran kolaboratif dengan pendekatan blended learning dikatakan berhasil untuk meningkatkan prestasi belajar mahasiswa. Peningkatan terjadi pada persentase jumlah mahasiswa yang mencapai KKM pada setiap siklus dan rerata skor prestasi belajar mahasiswa. Diharapkan dari hasil penelitian ini dapat dilakukan modifikasi pendekatan blended learning pada berbagai model pembelajaran dan juga pada mata matakuliah lainnya. Modifikasi model pembelajaran dengan pendekatan blended learning dapat menjadi alternatif solusi pembelajaran secara shifting selama pandemi Covid-19. Kendala pengurangan durasi tatap muka dapat diminimalisir sehingga pembelajaran menjadi lebih optimal.

\section{DAFTAR PUSTAKA}

[1] J. Macgregor, "Collaborative learning: Shared inquiry as a process of reform," New Dir. Teach. Learn., vol. 1990, no. 42, pp. 19-30, 1990, doi: 10.1002/t1.37219904204.

[2] D. H. Schunk, Learning theories: An educational perspective, vol. 5. 2012.

[3] C. Hartmann, J. C. Angersbach, and N. Rummel, "Social interaction, constructivism and their application within (CS)CL theories," Comput. Collab. Learn. Conf. CSCL, vol. 2, no. April, pp. 553-556, 2015.

[4] S. Husain, "Implementing StudentCentred And Collaborative Learning Based On Vygotsky's Social Constructivism Theory In Indonesian School Curriculum," Int. J. Manag. Appl. Sci., vol. 4, no. 7, pp. 23947926, 2018.

[5] K. Scager, J. Boonstra, T. Peeters, J. Vulperhorst, and F. Wiegant, "Collaborative learning in higher education: Evoking positive interdependence," CBE Life Sci. Educ., vol. 15, no. 4, pp. 1-9, 2016, doi: 10.1187/cbe.16-07-0219. 
[6] C. La Rocca, M. Margottini, and R. Capobianco, "Collaborative Learning in Higher Education," Open J. Soc. Sci., vol. 02, no. 02, pp. 61-66, 2014, doi: 10.4236/jss.2014.22009.

[7] M. Laal and M. Laal, "Collaborative learning: What is it?," Procedia Soc. Behav. Sci., vol. 31, pp. 491495, 2012, doi: 10.1016/j.sbspro.2011.12.092.

[8] M. Hosnan, Pendekatan Saintifik dan Kontekstual dalam Pembelajaran Abad 21. 2014.

[9] D. Darmawan, "Pendekatan Praktik Teknologi Mulitimedia dan Pembelajaran Online". Bandung: PT. Remaja Rosdakarya, 2012.

[10] S. So, "Mobile instant messaging support for teaching and learning in higher education," Internet High. Educ., vol. 31, pp. 32-42, 2016, doi: 10.1016/j.iheduc.2016.06.001.

[11] Y. C. Kuo, A. E. Walker, K. E. E. Schroder, and B. R. Belland, "Interaction, Internet self-efficacy, and self-regulated learning as predictors of student satisfaction in online education courses," Internet High. Educ., vol. 20, pp. 35-50, 2014 , doi: 10.1016/j.iheduc.2013.10.001

[12] E. Chew, N. Jones, and D. Turner, "Critical review of the blended learning models based on Maslow's and Vygotsky's educational theory," Lect. Notes Comput. Sci. (including Subser. Lect. Notes Artif. Intell. Lect. Notes Bioinformatics), pp. 40-53, 2008, doi: 10.1007/978-3-54085170-7_4.

[13] A. Ateş, "REVIEW: The Blended Learning Book: Best Practices, Proven Methodologies, And Lessons Learned," Turkish Online J. Distance Educ., vol. 11, pp. 225-228, 2010, doi: 10.17718/tojde.15117.

[14] J. C. Cronje, "Towards a new definition of blended learning,"
Electron. J. e-Learning, vol. 18, no. 2, pp. 114-135, 2020, doi: 10.34190/EJEL.20.18.2.001.

[15] D. N. Wardani, A. J. E. Toenlioe, and A. Wedi, Daya Tarik Pembelajaran Di Era 21 Dengan Blended Learning, vol. 1, no. 1. 2018.

[16] Kemendikbud, "Panduan Penyelenggaraan Pembelajaran pada Tahun Ajaran dan Tahun Akademik Baru di Masa Covid-19," 2020. https://www.kemdikbud.go.id/main/b $\log / 2020 / 06 /$ panduan-

penyelenggaraan-pembelajaran-padatahun-ajaran-dan-tahun-akademikbaru-di-masa-covid19.

[17] U. Hanifah Salsabila, L. Irna Sari, K. Haibati Lathif, A. Puji Lestari, and A. Ayuning, "Peran Teknologi Dalam Pembelajaran Di Masa Pandemi Covid-19," Al-Mutharahah J. Penelit. dan Kaji. Sos. Keagamaan, vol. 17, no. 2, pp. 188198, 2020, doi: 10.46781/almutharahah.v17i2.138.

[18] G. S. Sunardi, S. Joyoatmojo, S. Sajidan, and S. Soeharto, "Blended Learning-Based Self-directed Learning on Classroom Action Research Training to Improve Teacher Competency Research," J. Educ. Learn., vol. 10, no. 4, p. 327, 2016, doi: 10.11591/edulearn.v10i4.4516.

[19] Z. Amri, "Classroom Action Research And Lesson Study: How Do They Work For Lecturers And High School English Teachers," 2013. 